\title{
Landscape heterogeneity and the biodiversity of Arctic stream communities: a habitat template analysis
}

\author{
Alexander D. Huryn, Karie A. Slavik, Rex L. Lowe, Stephanie M. Parker, \\ Dennis S. Anderson, and Bruce J. Peterson
}

\begin{abstract}
We predicted that substratum freezing and instability are major determinants of the variability of stream community structure in Arctic Alaska. Their effects were conceptualized as a two-dimensional habitat template that was assessed using a natural experiment based on five stream types (mountain-spring, tundra-spring, tundra, mountain, glacier). Detrended correspondence analysis (DCA) indicated distinct macroinvertebrate assemblages for each stream type. The contribution of functional feeding groups to assemblage biomass varied systematically among stream types, indicating that structure and function are linked. Assemblage position within a DCA biplot was used to assess factors controlling its structure. Springs separated from other stream types along a gradient of nutrient concentration and freezing probability. Glacier and mountain streams separated from springs and tundra streams along a gradient of substratum instability and freezing probability. Owing to differences in sources of discharge to streams, the effects of nutrients and substratum stability could not be separated from freezing. Although many factors likely contribute to the variability of Arctic stream communities, the major determinants may be conceptualized as a template structured by gradients in (i) nutrient supply and substratum freezing and (ii) substratum instability and substratum freezing. This template provides a basis for predicting the response of Arctic stream communities to climate change.
\end{abstract}

Résumé : Nous avons prédit que le gel et l'instabilité du substrat sont des causes majeures de la variabilité de la structure des communautés des cours d'eau en Alaska arctique. Nous avons conceptualisé ces effets dans un cadre bidimensionnel de l'habitat qui a été évalué au cours d'une expérience en nature dans cinq types de cours d'eau (source montagneuse, source de toundra, toundra, montagne et glacier). Une analyse de correspondance redressée (DCA) révèle des peuplements caractéristiques de macroinvertébrés dans chacun des types de cours d'eau. La contribution des différentes guildes alimentaires fonctionnelles à la biomasse du peuplement varie systématiquement selon le type de cours d'eau, ce qui montre un lien entre la structure et la fonction. La position de chaque peuplement sur le graphique DCA bidimensionnel sert à évaluer les facteurs qui contrôlent sa structure. Les sources se séparent des autres types de cours d'eau le long d'un gradient de concentration de nutriments et de probabilité de gel. Les cours d'eau de montagne et de glaciers se distinguent des sources et des cours d'eau de toundra sur un gradient d'instabilité du substrat et de probabilité de gel. À cause des différentes sources des apports vers les cours d'eau, il est impossible de distinguer les effets des nutriments et de la stabilité du substrat de ceux du gel. Bien que de nombreux facteurs contribuent vraisemblablement à la variabilité des communautés des cours d'eau arctiques, on peut imaginer les principales causes déterminantes sur un cadre structuré par des gradients $(i)$ d'apports de nutriments + gel du substrat et (ii) d'instabilité du substrat + gel du substrat. Ce cadre fournit une base pour la prédiction des réponses des communautés d'eau courante de l'arctique au changement climatique.

[Traduit par la Rédaction]

\section{Introduction}

Streams show extraordinary variability in habitat structure over a broad range of spatial and temporal scales (Frissell et al. 1986; Rosgen 1994). Patterns of periphyton and macroinvertebrate community structure show similar variation, within and among streams, because their distribution is greatly influenced by habitat structure (Brussock et al. 1985; Huryn and

Received 19 February 2004. Accepted 28 March 2005. Published on the NRC Research Press Web site at http://cjfas.nrc.ca on 27 August 2005.

J17975

A.D. Huryn ${ }^{1}$ and S.M. Parker. Aquatic Biology Program, A122 Bevill Building, University of Alabama, Tuscaloosa, AL 354870206, USA.

K.A. Slavik ${ }^{2}$ and B.J. Peterson. The Ecosystems Center, Marine Biological Laboratory, Woods Hole, MA 02543, USA.

R.L. Lowe. Biology Department, Bowling Green University, Bowling Green, OH 43403, USA.

D.S. Anderson. Department of Biological Sciences, University of Maine, Orono, ME 04469, USA.

${ }^{1}$ Corresponding author (e-mail: huryn@bama.ua.edu).

${ }^{2}$ Present address: University of Michigan Biological Station, Ann Arbor, MI 48109, USA. 
Wallace 1987; Lowe and Pan 1996). As a consequence, the habitat-template approach (Southwood 1988) has been effective in predicting patterns of spatial and temporal variability in stream community structure (Scarsbrook and Townsend 1993; Townsend et al. 1997a; Biggs et al. 1998).

Attempts to apply habitat templates to streams have usually focused on gradients of disturbance intensity (Townsend et al. 1997b; Biggs et al. 1998). In this paper, we use a habitat template to test the prediction that the spatial variability of stream ecosystem structure and function in an Arctic landscape is based on the intensity of two disturbance regimes. The first is the movement of channel substrata in response to storm flows, which is identified as a major type of stream disturbance worldwide (Scarsbrook and Townsend 1993; Townsend et al. 1997b; Lake 2000). The second is winter freezing (Oswood et al. 1991; Irons et al. 1993), which imposes constraints on community structure similar to that of channel drying in intermittent streams (Clifford 1969). Streams that freeze solid or have intermittent flow will be inhabited only by taxa with life history stages able to survive periods without liquid water. Substratum freezing, which is assumed to contribute to the relative simplicity of Arctic stream communities (Oswood et al. 1995; Hershey et al. 1995), will presumably interact with substratum instability to provide an additional level of physical control on stream community structure (sensu Poff 1997). This interaction can be conceptualized as a two-dimensional habitat template with gradients of substratum instability and the probability of substratum freezing as its axes.

We assessed this habitat template using a natural experiment involving five stream types on the North Slope of Alaska (mountain-spring, tundra-spring, tundra, mountain, and glacier). Because of the harsh Arctic environment, we expected the community structure of all stream types to be simple and their community biomass low compared with their temperate counterparts. Within this constraint, we expected stream community structure and biomass to vary along a gradient of substratum instability and probability of substratum freezing among stream types, ranging from the spring streams with perennial flow and high bed stability to glacier streams, which freeze solid during winter and have low bed stability. We also expected that the landscape-scale gradients of these two major habitat variables would interact to produce a continuum of community complexity among stream types, with perennial springs having the highest community richness, trophic complexity, and biomass and glacier streams having the lowest.

\section{Methods}

\section{Study system}

The North Slope is divided into the Arctic Coastal Plain, Arctic Foothills, and Arctic Mountain physiographic provinces (Wahrhaftig 1965). The Arctic Mountain province contains the Brooks Range, with peaks exceeding $1800 \mathrm{~m}$ and numerous cirque glaciers. The Arctic Coastal Plain and the Arctic Foothills are covered by Quaternary sediments. On average, the North Slope receives $<150 \mathrm{~mm}$ of precipitation annually. The average temperature is $-29^{\circ} \mathrm{C}$ in January and $10{ }^{\circ} \mathrm{C}$ in July (Oswood et al. 1995). Vegetation generally consists of grasses, sedges, forbs, and shrubs $<1 \mathrm{~m}$ in height, although shrubs attaining heights of $1 \mathrm{~m}$ or more, primarily willows, occur along the banks of some streams and rivers.

Craig and McCart (1975) identified three types of headwater streams on the North Slope: mountain, tundra, and spring. Mountain streams are fed primarily by runoff from snowmelt and precipitation. Like mountain streams, the source of water to tundra streams is snowmelt and precipitation. Unlike mountain streams, however, their catchments are composed of peat underlain by an aquaclude formed by permafrost. Both mountain and tundra streams have peak flows during spring and early summer and low flows during late summer. With the onset of winter, runoff ceases, channel volume is reduced, and the water column freezes, although open water may persist in deep pools $(>2 \mathrm{~m})$ or regions of upwelling ground water (Craig 1989).

Spring streams provide a strong contrast to mountain and tundra streams because they have perennial flow and water temperatures that may exceed $5{ }^{\circ} \mathrm{C}$ year-round (Craig and McCart 1975). This is possible because they receive ground water from sources either below (subpermafrost) or within (suprapermafrost) the permafrost layer. The spring sources are connected to the groundwater reservoirs by unfrozen zones called talik (Prowse 1994). Spring streams in the Brooks Range (mountain springs) tend to occur on lower mountain slopes where outcrops of the Lisburne Limestone Group contact sandstone strata (Craig and McCart 1975). Springs occurring on the foothills and coastal plain (tundra springs) apparently receive discharge from deep lakes and other suprapermafrost sources associated with Tertiary sediments.

\section{Stream selection}

Streams were classified following Craig and McCart (1975). We parsed their classification further, however. Mountain streams were divided into mountain (MTN) and glacier (GLC) streams because of contrasts in the source of discharge. Spring streams were subdivided into mountain springs (MTNSPR) associated with the Lisburne Limestone Group and tundra springs (TNDSPR) associated with Tertiary sediments. Most streams were remote and could be accessed only by helicopter. As a consequence, streams were sampled on one or only a few occasions. Sampling for various parameters occurred from 1997 through 2004.

\section{Indicators of freezing and disturbance}

Water temperature and environmental indicators were used to determine whether streams had perennial flow or were intermittent because of complete freezing of the water column. Water temperature was measured during the winters of 2001-2002, 2002-2003, 2003-2004 in selected MTN and MTNSPR streams using digital recording thermometers. Environmental indicators of perennial flow included the occurrence of Dolly Varden (Salvelinus malma) and slimy sculpin (Cottus cognatus) (Craig 1989), stoneflies of the genus Zapada (Nemouridae) and the family Perlodidae, and aufeis (massive accumulations of ice that occur downstream of perennially flowing streams) (Craig and McCart 1975; Prowse 1994). Perlodid stoneflies and Zapada occur in high abundances only in streams documented to have perennial flow (A.D. Huryn, personal observation). Literature records stating whether a particular stream had perennial flow were 
used as an additional source of evidence (e.g., Nava and Morrison 1974; Craig and McCart 1975; Craig 1989).

A community-level indicator of cold hardiness (includes both true freeze tolerance and freeze avoidance strategies, Danks 1978) was developed using the macroinvertebrate community of Imnavait Creek, a headwater tributary of the Kuparuk River (Miller et al. 1986). This stream freezes solid during winter with benthic temperatures as low as $-10{ }^{\circ} \mathrm{C}$ being documented (Irons and Oswood 1992). We assume all the taxa in Imnaviat Creek (listed in Table 1 of Miller et al. 1986) must overwinter in stream substrata where they either tolerate freezing or avoid it by physiological and (or) behavioral means. The possibility that Imnaviat Creek is colonized by taxa after spring thaw is small because of the absence of perennial streams in the watershed. Our assumption seems reasonable given the documentation that Imnaviat Creek freezes solid and because most of the taxa listed by Miller et al. (1986) are larval Chironomidae, Empididae, and nemourid stoneflies, for which several taxa have been shown to survive freezing in laboratory experiments (Irons et al. 1993). A community-level indicator of cold hardiness was estimated for each of the study streams as the proportion of community biomass that consisted of taxa occurring in Imnaviat Creek combined with that consisting of Ephemeroptera and Simuliidae, which presumably overwinter in frozen substrata as eggs. This presumption is based on the observation (A.D. Huryn, unpublished data) that following spring thaw of streams documented to freeze solid, mayfly (Baetidae, Ephemerellidae) and simuliid larvae are absent until late June or early July, when they hatch from overwintering eggs. Overwintering as diapausing or quiescent eggs has been reported for numerous taxa of the Ephemeroptera (Clifford 1982) and Simuliidae (Crosskey 1990), and overwintering as cold-hardy eggs in particular has been reported by Clifford (1969) and Giberson and Galloway (1985) for selected Ephemeroptera and by Kurtak (1974) for the Simuliidae.

The relative intensity of physical disturbance was assessed using two indicators. The first was bryophyte biomass. The extent of bryophyte cover is widely used as an indicator of stream substratum instability (McAuliffe 1983; Duncan et al. 1999). The second was based on the community attributes of periphyton. Biggs et al. (1998) assigned common stream periphyton taxa to disturbance frequency categories (low, medium-low, medium-high, high). We used their classification to assign taxa of periphyton collected from our study streams to disturbance frequency categories. The proportion of cells from each sample indicating a high disturbance regime (i.e., proportion of cells representing taxa indicating high + medium-high disturbance regimes; see Appendix 1 in Biggs et al. 1998) was divided by the proportion of those indicating a low disturbance regime (i.e., proportion of cells representing taxa indicating low + medium-low disturbance regimes; see Appendix 1 in Biggs et al. 1998). These two proportions were arcsine-transformed prior to calculating the ratio. In some cases (two glacier streams and one mountain stream), either no periphyton at all or no taxa indicating a low or medium-low disturbance regime was present, so no ratio could be calculated. A value of 10 was assigned to these cases, which approximates the high range of the disturbance index estimated in this study.

\section{Community structure}

\section{Periphyton}

Periphyton was sampled from 1997 through 2000. Only a subset of streams could be sampled each year, however. Cobbles (90-128 mm diameter) were selected from riffles and placed in a plastic pan of known area $\left(0.05 \mathrm{~m}^{2}\right)$. Once the bottom of the pan was covered, periphyton was scrubbed from the entire surface of each cobble with a steel brush. The resulting slurry was rinsed into a known volume of stream water and a subsample was filtered onto a glass-fiber filter (Peterson et al. 1993). Chlorophyll $a$ was then extracted and measured fluorometrically. Periphyton community structure was determined by counting and identifying a minimum of 300 algal units at $450 \times$ magnification from homogenized periphyton slurries. Non-diatom algae were identified directly from wet mounts. Filaments were counted in units of 10 cells each. Diatoms were acid cleansed and mounted in Naphrax ${ }^{\circledR}$ prior to identification. Cell counts and chlorophyll $a$ biomass were standardized to square metres using the area of the sampling pan $\left(0.05 \mathrm{~m}^{2}\right)$.

\section{Macroinvertebrates}

A Surber sampler $(243-\mu \mathrm{m}$ mesh) was used to sample macroinvertebrates and bryophytes. All streams were sampled for macroinvertebrates and bryophytes on one date between 4 July and 2 August 2001 (Table 1), with the exception of Sadlerochit MTNSPR, which was sampled on 22 July 2002. Five samples were taken from at least two separate riffles in each stream (except for the Echooka and Kuparuk Upper, where only three samples were taken from a single riffle). Spring streams were sampled at least 100 $200 \mathrm{~m}$ below discernable groundwater sources. Substrata were scrubbed with a brush to dislodge bryophytes and detritus. Samples were preserved in $4 \%$ formaldehyde. Invertebrates were removed by hand under magnification. Bryophytes were retained for further processing (see below). Invertebrates were identified to the lowest practical taxonomic level, usually genus, and assigned to functional feeding groups. The latter designation was based on Merritt and Cummins (1996) and direct observations of gut contents. Biomass was estimated from measurements of body length using family-level length-mass relationships (Benke et al. 1999).

\section{Bryophytes}

Bryophytes were oven dried for $48 \mathrm{~h}$ at $60{ }^{\circ} \mathrm{C}$. Dry mass (DM) was measured and then the sample was ignited in a muffle furnace $\left(500{ }^{\circ} \mathrm{C}\right)$. The remaining ash mass was measured and was subtracted from DM to estimate ash-free dry mass (AFDM).

\section{Water chemistry, channel slope, and discharge}

Water chemistry and discharge were sampled from 1997 through 2000, concurrently with periphyton sampling (Table 1). Soluble, reactive phosphorus (SRP) and $\mathrm{NO}_{3}-\mathrm{N}+$ $\mathrm{NO}_{2}-\mathrm{N}$ were measured using colorimetric methods (Murphy and Riley 1962) from water samples filtered through 0.45 $\mu \mathrm{m}$ cellulose-acetate filters or precombusted glass-fiber filters with a nominal pore size of $0.7 \mu \mathrm{m}$. $\mathrm{NH}_{4}-\mathrm{N}$ was measured following Holmes et al. (1999). $\mathrm{pH}$ was measured in 


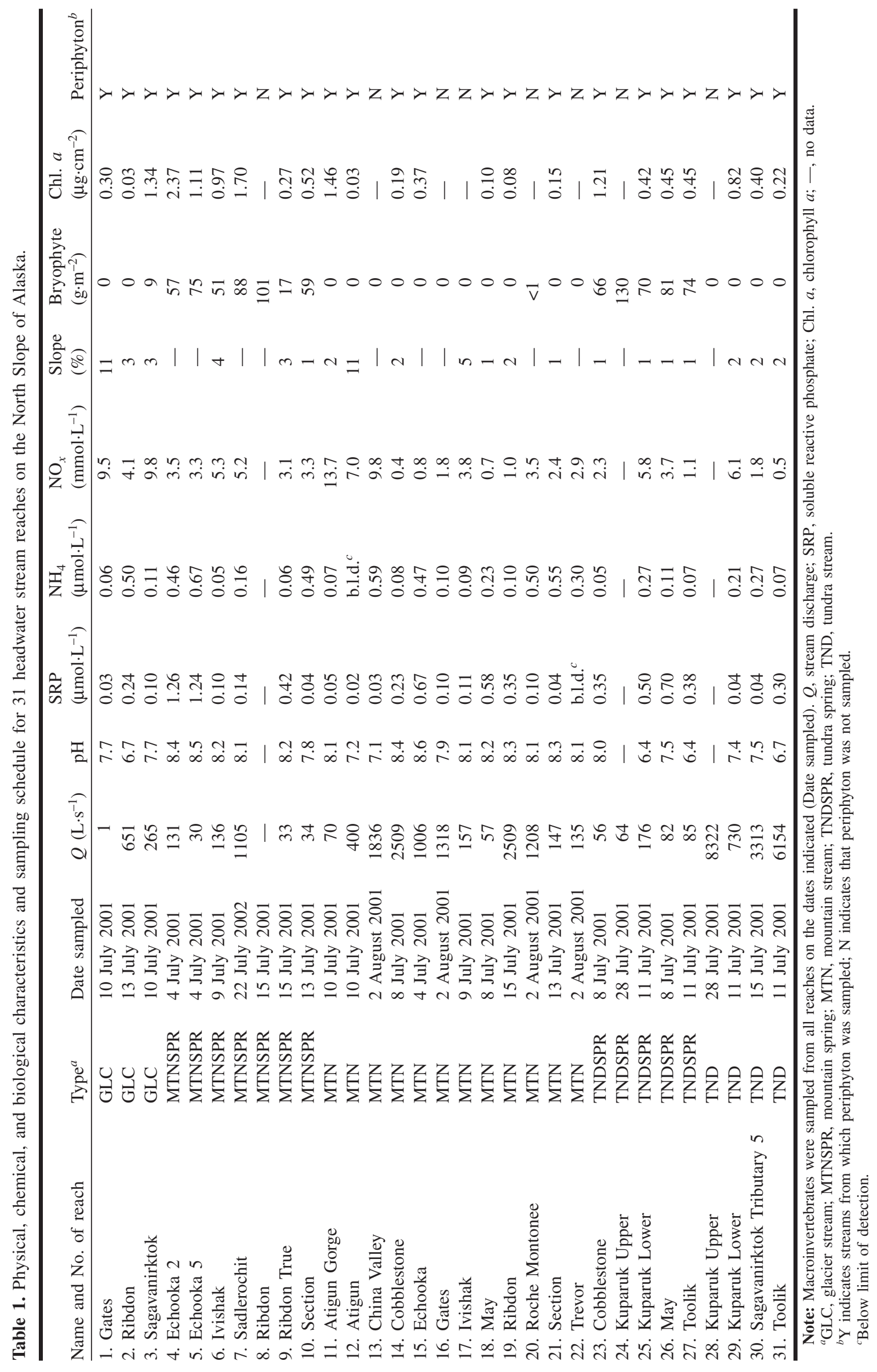


situ with a handheld meter. Channel slope was measured using a $15-\mathrm{m}$ plastic tube as a water level. Discharge was estimated from depth and current velocity transects.

\section{Analysis}

Differences in biological and physical parameters among stream types were primarily determined using one-way analysis of variance (ANOVA) followed by Tukey's least significant difference post hoc comparisons $(\alpha=0.05)$. For the analysis of bryophyte biomass, however, the Mann-Whitney $U$ test was used because of the presence of numerous zero values among streams. In all analyses, streams were used as replicates. In cases where replicated samples were taken from single streams (e.g., invertebrate samples), means were used to represent the stream. For parametric tests, proportions were arcsine-transformed and estimates of abundance and biomass were $\ln (x+1)$-transformed to enhance homogeneity of variance (Zar 1984). Detrended correspondence analysis (DCA; Hill and Gauch 1980; McCone and Mefford 1999) was used to produce an ordination of the study streams based on macroinvertebrate community structure (quantified as biomass). Species occurring at only one stream were omitted (10 taxa), and rare species were downweighted following McCone and Mefford (1999). Relationships between DCA axis loadings and selected biological and physical variables were assessed using correlation $(p$ $=0.05)$. In some cases, variables were $\ln (x+1)$-transformed to linearize relationships.

\section{Results}

Thirty-one stream reaches were sampled in the Colville, Kuparuk, Sagavanirktok, and Sadlerochit drainages (Fig. 1, Table 1). With the exceptions of Kuparuk Upper TND and Kuparuk Lower TND (Table 1), all reaches were on separate tributaries. Kuparuk Upper TND and Lower TND were upstream of the confluence of the Kuparuk mainstem with two different spring streams (Fig. 1). Kuparuk Upper TND was removed from ANOVA and correlation analyses a priori to avoid pseudoreplication.

\section{Indicators of freezing}

During the winter of 2001-2002, water temperatures never fell below $1{ }^{\circ} \mathrm{C}$ for both Echooka and Ivishak MTNSPR, indicating perennial flow (Table 2). Other indicators and literature records for the remaining MTNSPR and TNDSPR suggest that these springs are also perennial, with the exception of Kuparuk Upper TNDSPR (Table 2). The assumption that stream types other than springs had intermittent flow due to freezing (e.g., Craig 1989) was not supported. Minimum temperatures measured in Echooka MTN and Ivishak MTN ranged from -0.1 to $0.2{ }^{\circ} \mathrm{C}$, respectively, indicating that complete freezing probably did not occur. In addition, putative indicators of perennial flow (e.g., Perlodidae, Zapada sp.) suggested that several other MTN and TND streams might have perennial flow (Table 2).

The proportion of biomass attributable to cold-hardy macroinvertebrates ranged from $99 \%$ for Atigun MTN to $46 \%$ for Cobblestone TNDSPR. The macroinvertebrate communities of GLC $(95 \% \pm 2 \%$; mean \pm SE), MTN $(85 \% \pm$ $3 \%)$, and TND $(88 \% \pm 3 \%)$ streams had higher proportions of cold-hardy biomass than those of MTNSPR $(67 \% \pm 4 \%)$ and TNDSPR $(60 \% \pm 5 \% ; p<0.05)$.

\section{Indicators of substratum instability}

\section{Bryophytes}

Bryophyte biomass ranged from 0 (17 of 31 streams) to $130 \mathrm{~g}$ AFDM $\cdot \mathrm{m}^{-2}$ (Kuparuk Upper TNDSPR) among streams. Bryophyte biomass in TNDSPR and MTNSPR was greater than other stream types (Mann-Whitney $U$ test, $p \leq$ $0.04)$.

\section{Periphyton}

Taxa indicating a high to moderately high disturbance regime (Appendix 1 in Biggs et al. 1998) were Achnanthidium biasolettianum, Achnanthidium minutissima, Cocconeis placentula, Fragilaria vaucheriae, Synedra rumpens, and Ulothrix zonata. Taxa indicating a low to moderately low disturbance regime were Audouinella sp., Batrachospermum sp., Diatoma hiemale, Draparnaldia sp., Meridion circulare, Mougeotia sp., Navicula cryptocephala, Nostoc sp., Synedra ulna, and Tolypothrix sp. The disturbance index ranged from 0.2 at Kuparuk Lower TNDSPR to 10.0 in Ribdon GLC and Sagavanirktok GLC. GLC had a significantly higher disturbance index $(8.9 \pm 1.1$; mean \pm SE) than TND $(3.0 \pm 1.9)$, MTNSPR (3.0 \pm 1.2$)$, and TNDSPR $(1.0 \pm 0.4$; ANOVA, $p$ $=0.012)$. The disturbance index of MTN $(4.5 \pm 1.0)$ did not differ significantly from other stream types.

\section{Community structure}

\section{Periphyton}

One hundred and twenty periphyton taxa were identified from 24 streams (Table 1). The diatoms Achnanthidium biasolettianum, Achnanthidium minutissima, Encyonema minutum, Fragillaria vaucheriae, and Hannea arcus and cyanobacteria Oscillatoria sp. and Schizothrix calcicola were widespread, occurring in at least $75 \%$ of the 24 streams sampled for periphyton. Taxonomic richness ranged from five taxa in Gates GLC to 42 in Cobblestone TNDSPR. The number of taxa in TNDSPR and MTNSPR was greater than those in MTN and GLC (Fig. 2, ANOVA, $p=0.019$ ). Diatom species richness followed the same trend as total periphyton richness (Fig. 2, $p=0.037$ ). Algal abundance was greater in TNDSPR and MTNSPR than in MTN (Fig. 2, $p=0.037)$. Diatom abundance in GLC was lower than in other stream types (Fig. 2, $p<0.005$ ). Benthic chlorophyll ranged from $0.03 \mu \mathrm{g} \cdot \mathrm{cm}^{-2}$ (Ribdon GLC, Atigun MTN) to $2.37 \mu \mathrm{g} \cdot \mathrm{cm}^{-2}$ (Echooka $2 \mathrm{MTNSPR}$ ), but did not differ among stream types (Table 1 , ANOVA, $p=0.311$ ).

\section{Macroinvertebrates}

Seventy-two macroinvertebrate taxa were identified; 31 were genera of the Chironomidae. The Oligochaeta and the chironomid genera Diamesa and Eukiefferiella were the most widespread, occurring in $>94 \%$ of streams. Ten taxa occurred only in a single stream. Taxonomic richness ranged from 11 taxa in Ribdon GLC and Gates GLC to 41 in Toolik TND. The community of Sadlerochit MTNSPR was dominated by the amphipod Gammarus sp.; the gastropod Fossaria sp.; the mayfly Baetis cf. tricaudatus; the caddisflies Glossosoma intermedium, Brachycentrus 
Fig. 1. Map of the eastern North Slope of Alaska showing study streams.Stream types are as follows: MTN, mountain stream; GLC, glacier stream; TND, tundra stream; TNDSPR, tundra spring; MTNSPR, mountain spring. Numbers in figure correspond with the following: 1, Gates GLC; 2, Ribdon GLC; 3, Sagavanirktok GLC; 4, Echooka 2 MTNSPR; 5, Echooka 5 MTNSPR; 6, Ivishak MTNSPR; 7, Sadlerochit MTNSPR; 8, Ribdon MTNSPR; 9, Ribdon True MTNSPR; 10, Section MTNSPR; 11, Atigun Gorge MTN; 12, Atigun MTN; 13, China Valley MTN; 14, Cobblestone MTN; 15, Echooka MTN; 16, Gates MTN; 17, Ivishak MTN; 18, May MTN; 19, Ribdon MTN; 20, Roche Montonee MTN; 21, Section MTN; 22, Trevor MTN; 23, Cobblestone TNDSPR; 24, Kuparuk Upper TNDSPR; 25, Kuparuk Lower TNDSPR; 26, May TNDSPR; 27, Toolik TNDSPR; 28, Kuparuk Upper TND; 29, Kuparuk Lower TND; 30, Sagavanirktok Tributary 5 TND; 31, Toolik TND.

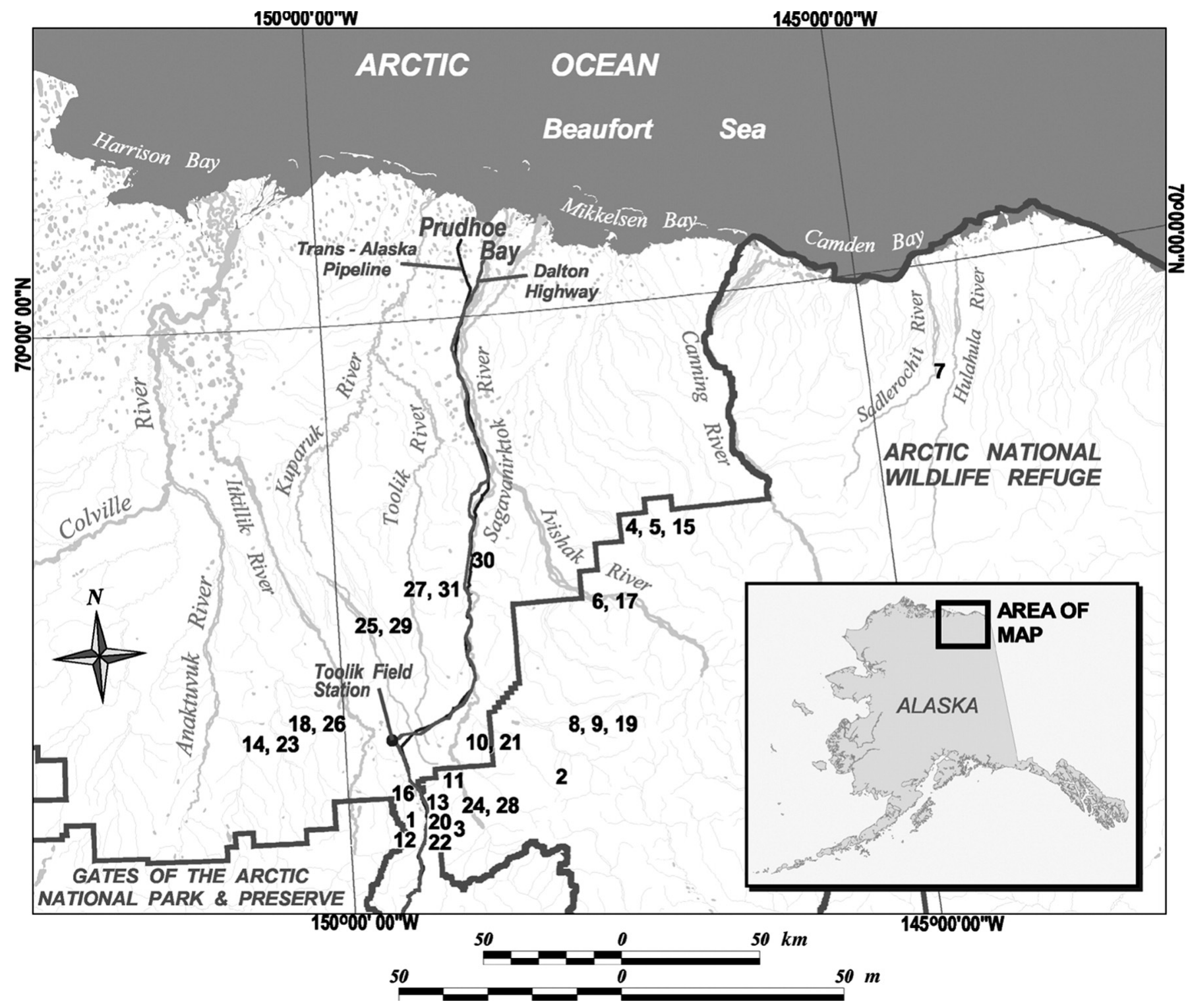

americanus, and Onocosmoecus unicolor; and the stoneflies Skwala sp. and Diura sp. Together, these contributed $69 \%$ of biomass in Sadlerochit Spring compared with $<2 \%$ in the other streams ( $0 \%$ in 27 streams). Because of its unique fauna, Sadlerochit MTNSPR was removed from further statistical analyses.

Macroinvertebrate abundance ranged over three orders of magnitude among streams. Mean abundance in TNDSPR $\left(1.2 \times 10^{5} \pm 5.3 \times 10^{4}\right.$ individuals. $\left.\mathrm{m}^{-2}\right)$ and MTNSPR $(9.2 \times$ $10^{4} \pm 3.4 \times 10^{4}$ individuals $\left.\cdot \mathrm{m}^{-2}\right)$ was greater than that in $\operatorname{MTN}\left(4.2 \times 10^{3} \pm 0.7 \times 10^{3}\right.$ ind. $\cdot \mathrm{m}^{-2}$; ANOVA, $p=0.003$; Fig. 3). Biomass, which ranged over two orders of magni- tude among streams, was greater in MTNSPR (5800 \pm $\left.1647 \mathrm{mg} \mathrm{DM} \cdot \mathrm{m}^{-2}\right)$ than in GLC $(442 \pm 261)$ and MTN (399 $\pm 83 \mathrm{mg} \mathrm{DM} \cdot \mathrm{m}^{-2} ; p<0.001$; Fig. 3).

DCA indicated that macroinvertebrate community structure was distinct among stream categories selected a priori (Craig and McCart 1975; Fig. 4). There were exceptions, however. Section MTNSPR grouped with TNDSPR. Kuparuk Upper TNDSPR grouped with MTN. The latter observation can be explained by a record of water temperatures for Kuparuk Upper TNDSPR from the winter of 2002-2003, which showed water column temperatures $<-4.0{ }^{\circ} \mathrm{C}$, indicating that this apparent TNDSPR freezes (Table 2). This 
Table 2. Summary of evidence indicating whether a stream is likely to freeze solid during winter.

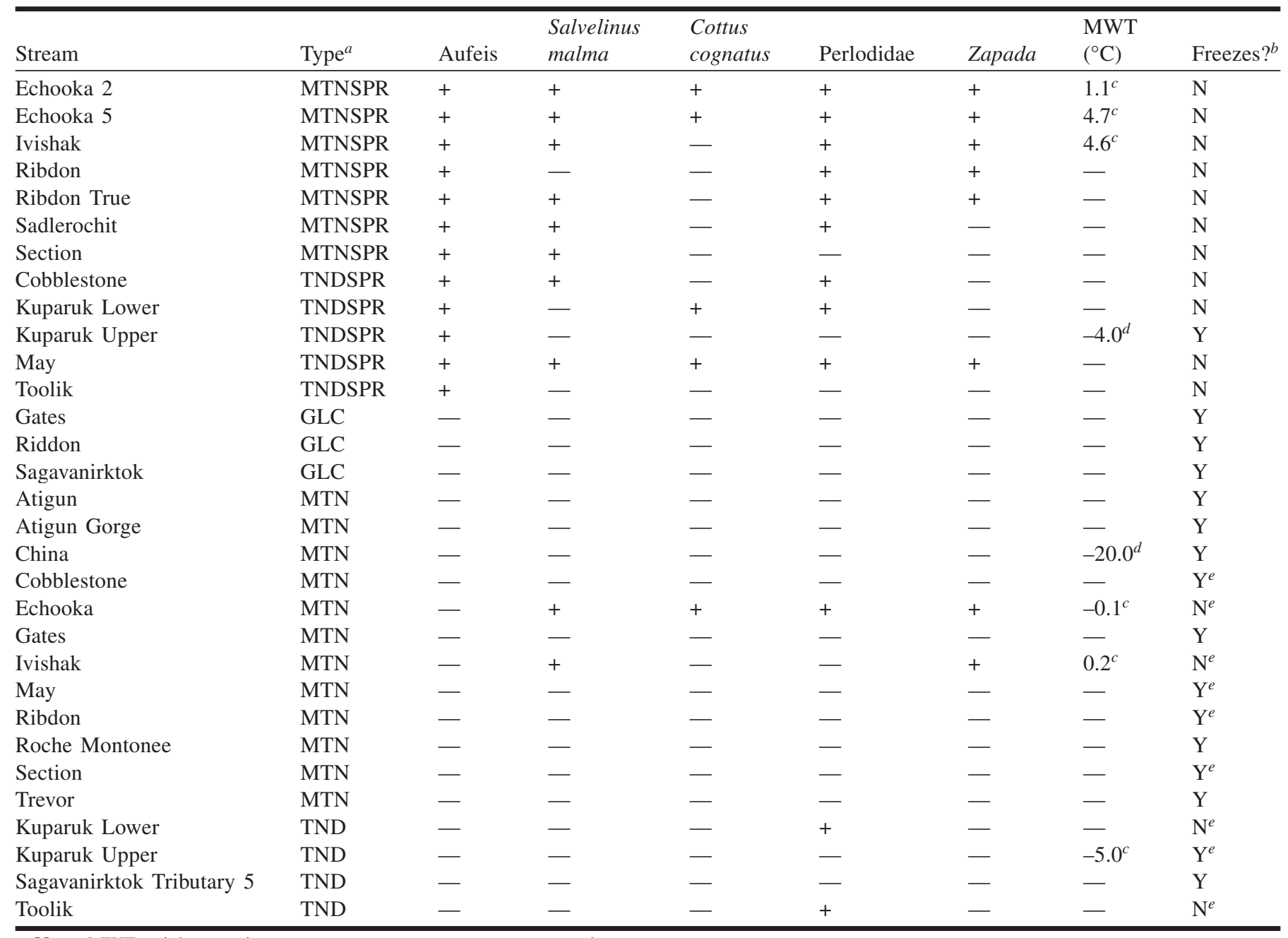

Note: MWT, minimum winter water temperature; +, presence; - , absence.

${ }^{a}$ GLC, glacier stream; MTNSPR, mountain spring; MTN, mountain stream; TNDSPR, tundra spring; TND, tundra stream.

${ }^{b}$ Assessment of whether stream freezes solid (Y, yes) or remains flowing (N, no) during winter. In the absence of actual measurements of winter water temperature, streams without indicators of perennial flow are assumed to freeze solid.

${ }^{c}$ Measured during winter 2001-2002.

${ }^{d}$ Measured during winter 2002-2003 or 2003-2004.

${ }^{e}$ Associated with spring streams. Channels of these streams may have localized areas of upwelling ground water.

stream also had no biological indicators of perennial flow, as would be expected for a stream that freezes (Table 2). With these exceptions, MTNSPR and TND formed discrete clusters. TNDSPR, GLC, and MTN, although more dispersed, occurred in consistent regions of the DCA biplot of Axes 1 and 2. The first two DCA axes represented $30.4 \%$ of total variance, as measured by correlation between Euclidian distance among sample units in the ordination and relative Euclidean distance in the original sample space

\section{Functional feeding group organization}

Filter feeder biomass ranged over five orders of magnitude among stream types $\left(0.09-374 \mathrm{mg} \mathrm{DM} \cdot \mathrm{m}^{-2}\right)$. The proportion of macroinvertebrate biomass contributed by filter feeders was greater in TND $(36 \% \pm 9 \%$; ANOVA, $p<$ 0.001 ; Fig. 5) than in other stream types, where they never comprised more than $2 \%$ of biomass. TND also had significantly greater filter feeder biomass than the other stream types $(p<0.001)$. Filter feeders were essentially absent from GLC. The Simuliidae, Brachycentridae, and selected members of the Tanytarsini were the only filter feeders recognized.

Predator biomass in MTNSPR $\left(1881 \pm 820 \mathrm{mg} \mathrm{DM} \cdot \mathrm{m}^{-2}\right)$ was one to two orders of magnitude greater than in other stream types (range: $17-247 \mathrm{mg} \mathrm{DM} \cdot \mathrm{m}^{-2}$ ) and was significantly greater in MTNSPR than in MTN (ANOVA, $p<$ 0.001 ; Fig. 5). The contribution of predators to macroinvertebrate biomass was greatest in MTNSPR $(26 \% \pm 7 \%$, $p<0.001)$. They contributed $<6 \%$ to macroinvertebrate biomass in the other stream types. Perlodid stoneflies (Arcynopteryx compacta and Isoperla sobria) contributed an average of $87 \%$ to predator biomass in MTNSPR.

The Diamesinae, Orthocladiinae, and Baetidae were widespread scrapers, the Oligochaeta and the Orthocladiinae and selected Tanytarsini were widespread collector-gatherers, and the nemourid stoneflies (Nemoura, Podmosta, Zapada) 
Fig. 2. (a) Total algal taxonomic richness $(\mathrm{S}),(b)$ total algal abundance, $(c)$ diatom taxonomic richness $(\mathrm{S})$, and $(d)$ total diatom abundance in five types of headwater streams in arctic Alaska. Error bar $=+1$ standard error. Bars with similar letters are not significantly different $(p=0.05)$. MTN, mountain stream; GLC, glacier stream; TND, tundra stream; TNDSPR, tundra spring; MTNSPR, mountain spring.
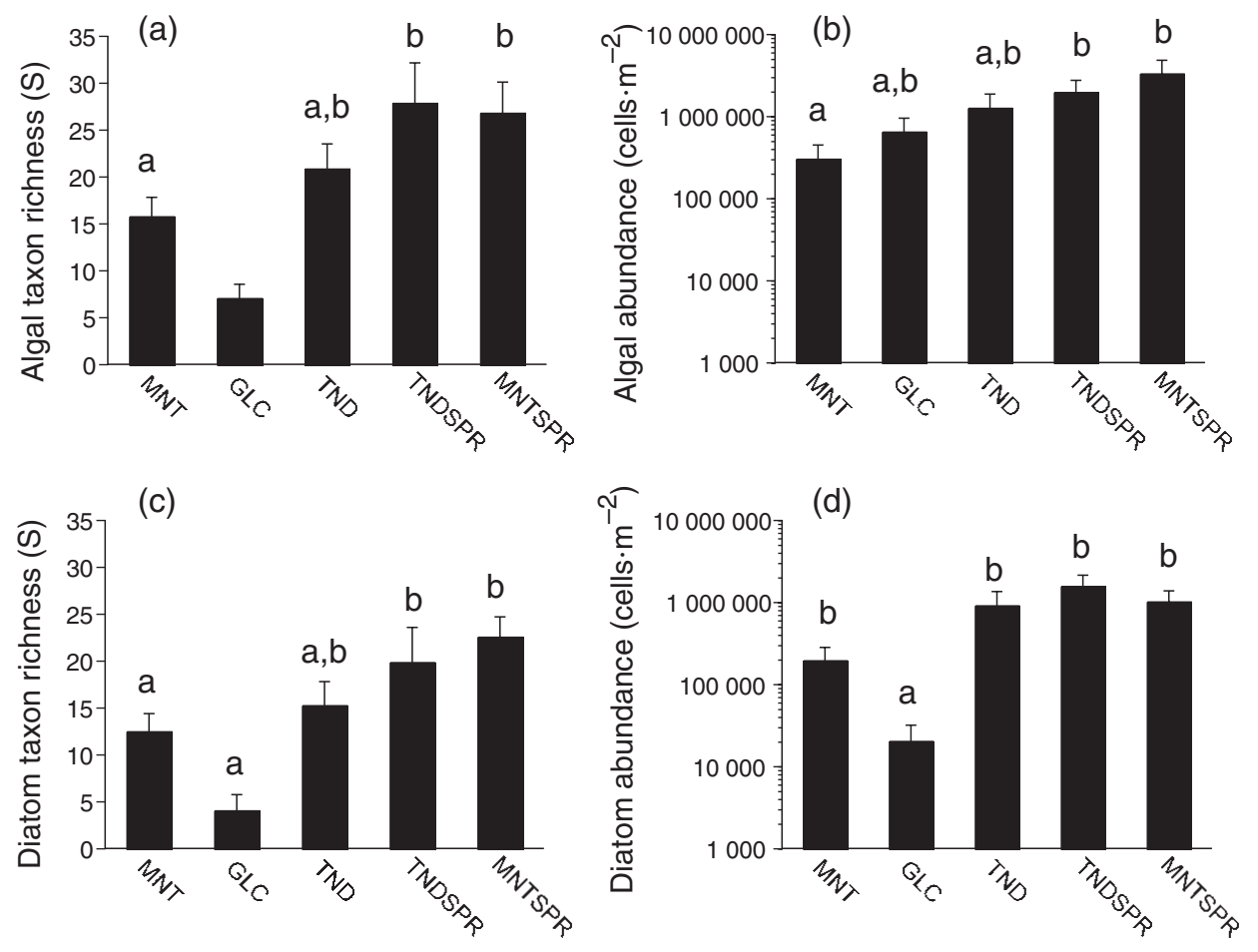

Stream type

were widespread shredders (Fig. 4). There were no significant differences in the proportional contributions of these functional feeding groups to total macroinvertebrate biomass among stream types (ANOVA, $p>0.05$ ).

\section{Water chemistry, discharge, and slope}

SRP ranged from $0.02 \mu \mathrm{mol} \cdot \mathrm{L}^{-1}$ in Atigun MTN to $1.26 \mu \mathrm{mol} \cdot \mathrm{L}^{-1}$ in Echooka $2 \mathrm{MTNSPR}$. $\mathrm{NO}_{3}-\mathrm{N}+\mathrm{NO}_{2}-\mathrm{N}$ ranged from $0.4 \mathrm{mmol} \cdot \mathrm{L}^{-1}$ in Cobblestone MTN to $13.7 \mathrm{mmol} \cdot \mathrm{L}^{-1}$ in Atigun Gorge MTN. $\mathrm{NH}_{4}-\mathrm{N}$ ranged from undetectable in Atigun MTN to $0.67 \mu \mathrm{mol} \cdot \mathrm{L}^{-1}$ in Echooka 5 MTNSPR. Nutrient concentrations did not differ among stream types, however (Table 1, ANOVA, $p>0.15$ ). $\mathrm{pH}$ ranged from 6.4 in Toolik TNDSPR to 8.6 in Echooka MTN. The $\mathrm{pH}$ of MTNSPR and MTN streams was higher than that of TNDSPR $(p=0.008)$. Discharge ranged from $1 \mathrm{~L} \cdot \mathrm{s}^{-1}$ (Gates GLC) to $8322 \mathrm{~L} \cdot \mathrm{s}^{-1}$ (Kuparuk Upper TND). Discharge of TND was significantly greater than MTNSPR, TNDSPR, and GLC (Table $1, p<0.05$ ). This latter finding should be treated with caution, however, because discharge of stream types other than springs varies widely over time, and measurements of discharge were usually taken on a single date. Channel slope ranged from $1 \%$ to $11 \%$ but did not vary significantly among stream types (Table $1, p=0.167$ ).

\section{Habitat template}

DCA Axis 1 is anchored at its extremes by TND and MTNSPR streams, with MTN, GLC, and TNDSPR streams dispersed between, while DCA Axis 2 is anchored by MTNSPR, TNSPR, and TND streams at one extreme and by
GLC streams at the other, with MTN streams dispersed between (Fig. 4). We initially presumed that Axis 1 represented a freezing gradient, because TND streams were expected to freeze, while MTNSPR were expected to have perennial flow; additionally, Axis 2 represented a substratum instability gradient because of constant discharge and low sediment supply to MTNSPR streams and variable discharge and high sediment supply to GLC and MTN streams.

Following these presumptions, we predicted that the proportion of macroinvertebrate biomass attributed to coldhardy taxa would be positively correlated with Axis 1 but would show no correlation with Axis 2. We also predicted that the disturbance index would be negatively correlated with Axis 2 but would show no correlation with Axis 1. Correlation analysis supported each of these predictions with the exception of a significant negative correlation between the proportion of cold-hardy biomass and Axis 2 (Fig. 6). The distribution of streams designated likely to freeze or likely to be perennial within the biplot of DCA axes showed that streams with loadings $<140$ on Axis 1 do not freeze, whereas those with loadings $<140$ on Axis 2 do freeze (Fig. 7). Streams with greater loadings on each axis showed variable freezing probabilities (Fig. 7).

The presence of TND and MTNSPR streams at each of the extremes of Axis 1 suggested that a nutrient gradient might provide an alternative interpretation for this axis (e.g., nutrient gradient rather than a freezing gradient). This is because the productivity of North Slope streams is limited by phosphorous rather than by nitrogen compounds, with TND streams being particularly oligotrophic (Harvey et al. 1998; 
Fig. 3. Mean macroinvertebrate abundance and biomass in five types of headwater streams in arctic Alaska. Error bar $=+1$ standard error. Bars with similar letters are not significantly different ( $p=0.05)$. MTN, mountain stream; GLC, glacier stream; TND, tundra stream; TNDSPR, tundra spring; MTNSPR, mountain spring.
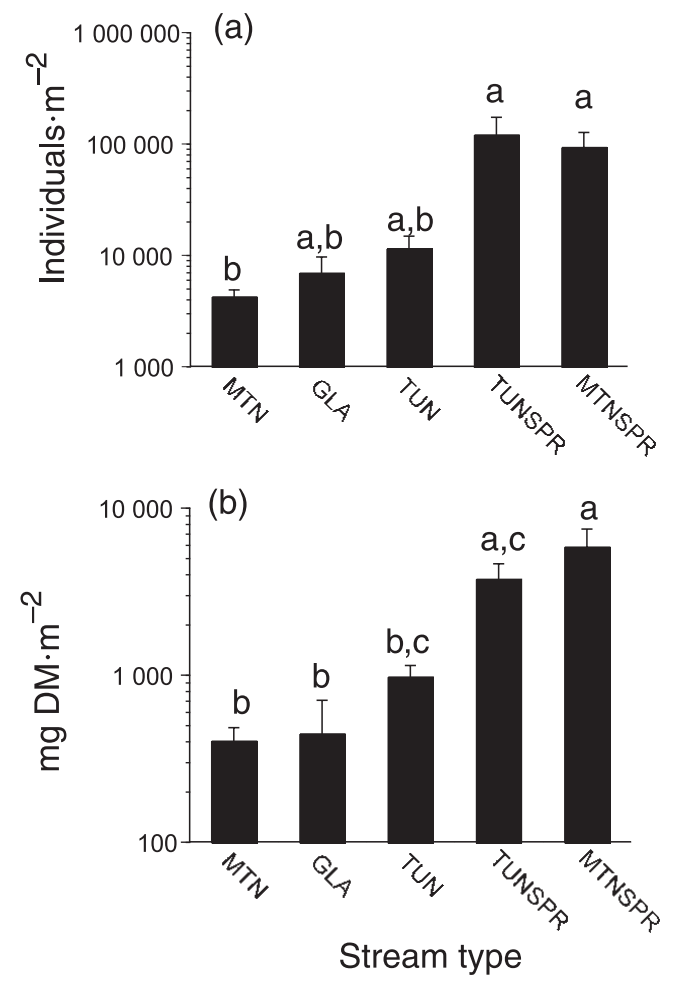

Slavik et al. 2004). This alternative was assessed by testing the predictions that SRP concentration would be negatively correlated with Axis 1 but not with Axis 2. Correlation analysis supported this prediction (Fig. 6).

The results of this analysis indicated that Axis 1 may be interpreted as both a freezing and nutrient gradient, whereas Axis 2 may be interpreted as both a freezing and disturbance gradient (Fig. 7). Following this, we predicted that chlorophyll $a$ biomass and bryophyte biomass would be negatively correlated with Axis 1, which represents a putative gradient in nutrient supply, while periphyton species richness and bryophyte and chlorophyll $a$ biomass would be positively correlated with Axis 2, which represents a putative gradient in substratum instability. These data are independent of the macroinvertebrate data used to derive the DCA axes. The basis for our predictions concerning Axis 1 is Slavik et al. (2004), who reported that periphyton and bryophyte biomass responds positively to experimental increases in SRP supply to tundra streams. The predictions for Axis 2 are based on the assumption that biomass of primary producers would not accumulate under conditions of repeated scouring and that only a small subset of the regional pool of periphyton taxa would be able to persist in streams with the highest levels of substratum disturbance. Correlation analysis supported both predictions for Axis 1 (Fig. 8). The predictions for Axis 2 were also supported with the exception of chlorophyll $a$. It should be noted, however, that the slope of the relationship between Axis 2 and chlorophyll $a$ was positive as predicted (Fig. 8).

\section{Discussion}

The streams of the North Slope show great physical and hydrological variability (Craig and McCart 1975; Craig 1989). This is reflected in the structure of their macroinvertebrate communities. The regional pool of taxa $(\beta$-richness $\sim 70+$ taxa), although small compared with streams at lower latitudes (Oswood 1989), comprises five assemblages structured by the position of a stream within this Arctic landscape. The range of community biomass among streams is unexpectedly large for streams draining a landscape underlain by continuous permafrost, being similar to that found worldwide (Fig. 9; Benke 1993). The contribution of different functional feeding groups to total biomass varies systematically among stream types, indicating that differences in community structure are linked to differences in ecosystem function.

\section{The habitat template}

Three major factors contribute to the habitat template underlying patterns of stream community structure on the North Slope: substratum freezing, substratum instability, and nutrient supply. As a consequence of systematic differences in sources of water to different stream types, however, the effect of substratum freezing on community structure could not be separated from those of substratum instability or nutrient supply. For example, spring streams that have discharge derived from ground water tended to have the lowest probability of freezing and the highest concentrations of SRP. In comparison, the mountain and glacier streams that have discharge originating from shallow interflow tended to have the highest probability of freezing and the highest degree of substratum instability. Although many factors likely contribute to the spatial variation of stream community structure in this region, our results indicate that the major factors may be conceptualized as a two-dimensional habitat template structured by a gradient in ( $i$ ) nutrient supply and freezing probability and (ii) substratum instability and freezing probability.

\section{Freezing}

The effect of freezing on stream communities (Olsson 1981; Oswood et al. 1991; Irons et al. 1993) parallels that of channel drying in intermittent streams (Clifford 1969). Streams affected by either or both of these conditions are inhabited by taxa with life history stages able to survive periods without liquid water. Experiments have failed to show widespread cold hardiness among Arctic stream invertebrates (Oswood et al. 1991; Irons et al. 1993). Nevertheless, some do survive freezing, as indicated by their occurrence as overwintering larvae in streams that freeze solid (Miller et al. 1986; Irons and Oswood 1992). These include members of the Chronomidae, Empididae, Nemouridae, and Tipulidae. Others, such as the Baetidae, Ephemerellidae, and Simuliidae, apparently survive freezing as eggs, as shown for selected ephemeropteran and simuliid taxa elsewhere (Clifford 1969; Kurtak 1974; Giberson and Galloway 1985). Taxa able to 


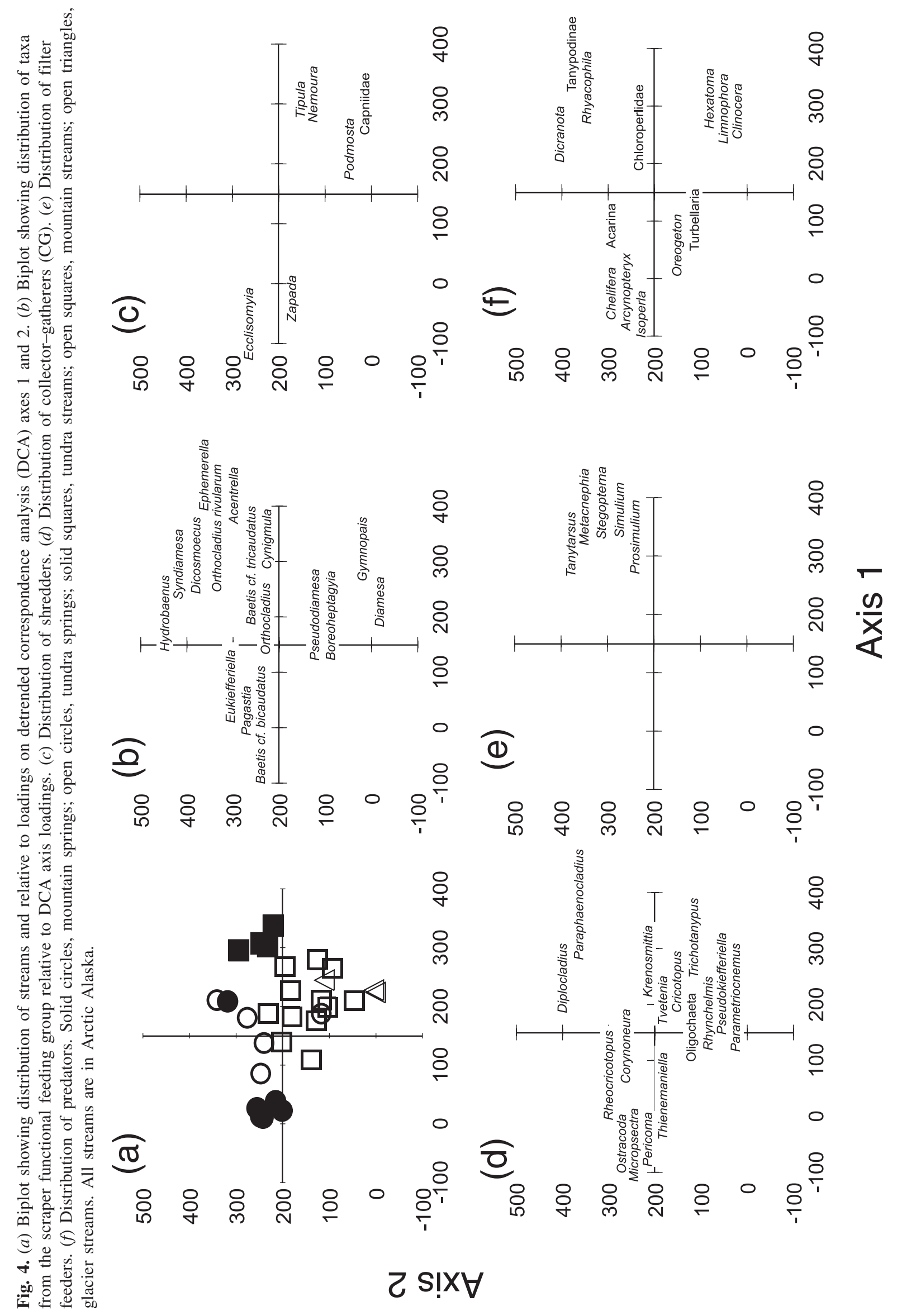


Fig. 5. Percent total macroinvertebrate biomass for filter feeders $(a)$ and predators $(b)$ and total biomass (DM, dry mass) for filter feeders $(c)$ and predators $(d)$ in five types of headwater streams in Arctic Alaska. Error bar $=+1$ standard error. Bars with similar letters are not significantly different $(p=0.05)$. MTN, mountain stream; GLC, glacier stream; TND, tundra stream; TNDSPR, tundra spring; MTNSPR, mountain spring.

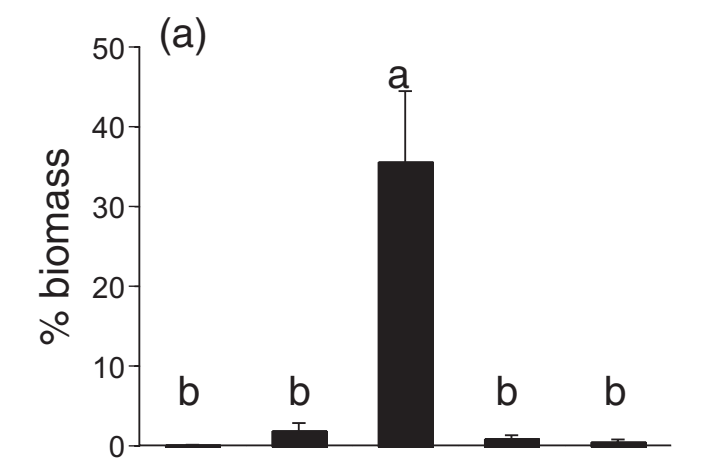

(b)
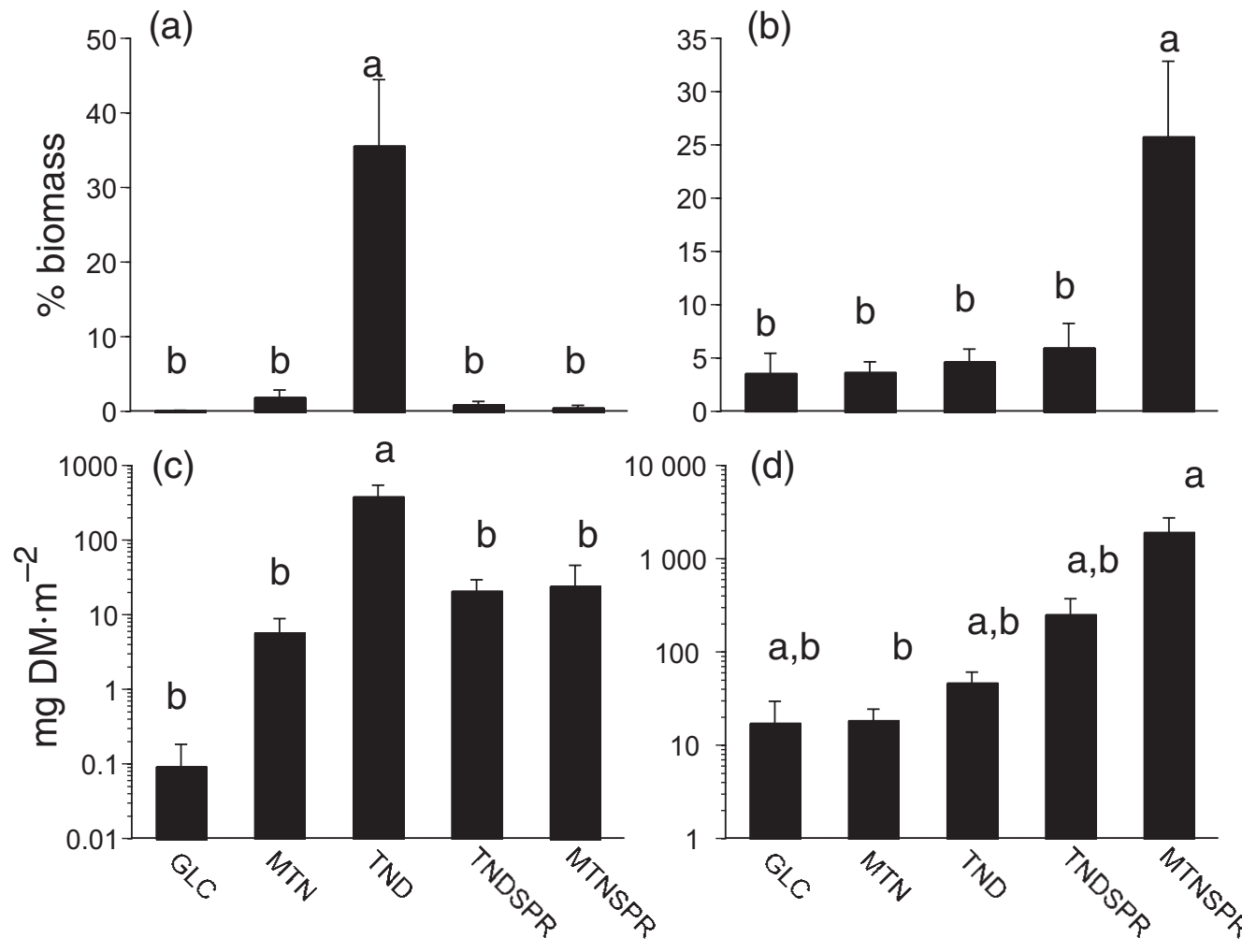

\section{Stream type}

tolerate freezing appear to form a core subset of the regional pool of stream macroinvertebrates on the North Slope.

The relationship between freezing and community structure can be illustrated by dividing the study streams into categories based on the strength of evidence indicating the probability of their freezing solid. Streams for which evidence of substratum freezing is strongest also have community biomass composed mainly of taxa known to persist in freezing streams (i.e., Miller et al. 1986; Irons and Oswood 1992). Streams with perennial flow have the lowest proportion of community biomass contributed by such cold-hardy taxa. Many streams have intermediate proportions, however. These are primarily tundra and mountain streams in drainages where springs are present. The possibility that their channels have localized areas of upwelling from groundwater or deep hyporheic sources that provide a refuge from substratum freezing is reasonable. Our results indicate that such refuges may be widespread in and among North Slope streams. Awareness of the existence and ecological role of such refuges will facilitate understanding factors underlying differences in community structure among the streams of this Arctic landscape.

\section{Substratum instability and nutrient supply}

Substratum instability is a fundamental determinant of stream community structure (Scarsbrook and Townsend 1993; Townsend et al. 1997a; Biggs et al. 1998). We anticipated that spring streams (MTNSPR, TNDSPR) would have communities indicating low levels of substratum disturbance due to constant discharge and low sediment supply and that the other stream types, with high discharge variability and sediment supply, would have communities indicating high levels of substratum disturbance. A disturbance index using periphyton as indicator taxa (Biggs et al. 1998), however, suggested that spring streams and tundra streams had lowintensity disturbance regimes, while a separate indicator of disturbance - bryophyte cover — provided a conflicting result. The presence of high bryophyte biomass in the springs indicated high substratum stability, while the presence of low bryophyte biomass in the tundra streams indicated low substratum stability. This discrepancy may be at least partially explained by the interaction between SRP supply and disturbance regime among stream types.

Phosphorous is the primary nutrient limiting the production of stream bryophytes in the study area (Peterson et al. 1993; Bowden et al. 1994). For the past two decades, the SRP supply has been experimentally increased in the Kuparuk River, an oligotrophic tundra stream (Slavik et al. 2004). This treatment enhanced growth of bryophytes in the treatment reach relative to a reference reach (Slavik et al. 2004). For example, bryophyte biomass in the treatment reach was $58 \mathrm{~g} \mathrm{AFDM} \cdot \mathrm{m}^{-2}$ in 2001 while bryophyte biomass was $<1 \mathrm{~g}$ AFDM $\cdot \mathrm{m}^{-2}$ in the reference reach (A.D. Huryn, unpublished data). This experiment provides evidence that increased SRP supplies may result in high bryophyte biomass in tundra streams. The contrast in bryophyte cover be- 
Fig. 6. Relationship between percent macroinvertebrate biomass attributable to cold-hardy taxa and detrended correspondence analysis (DCA) axes $1(a)$ and $2(b)$ for five types of headwater streams. Relationship between the disturbance index and DCA Axes $1(c)$ and $2(d)$. Relationship between soluble reactive phosphate (SRP) concentration and DCA Axes $1(e)$ and $2(f)$. Solid circles, mountain springs; open circles, tundra springs; solid squares, tundra streams; open squares, mountain streams; open triangles, glacier streams. All streams are in Arctic Alaska.
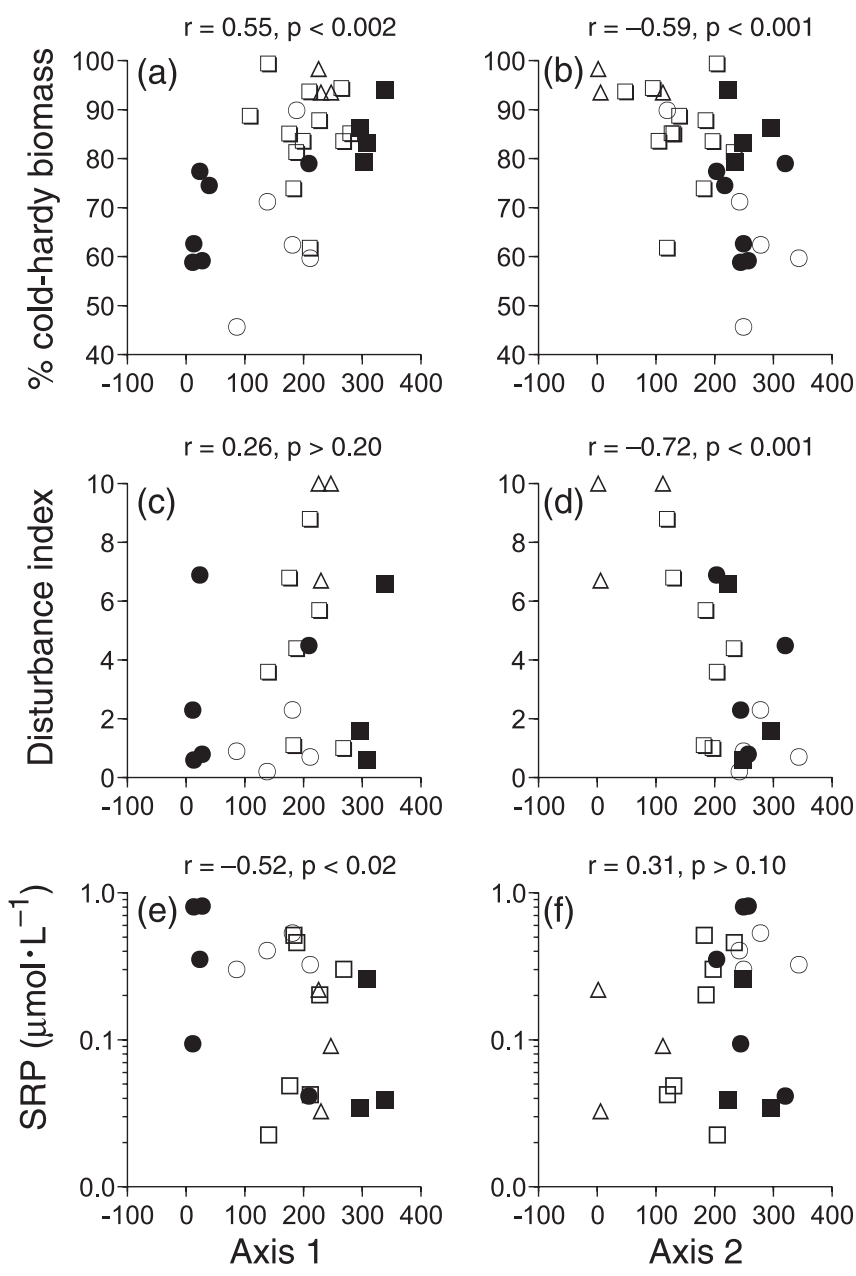

tween tundra and spring streams may thus be a response to SRP supply rather than substantial differences in substratum instability (McAuliffe 1983; Duncan et al. 1999).

The relationship among bryophyte biomass, SRP supply, and substratum instability is probably a dynamic one. If increased SRP supply enhances growth rate, bryophyte biomass will tend to recover more rapidly following a disturbance in nutrient-rich than in nutrient-poor streams. Accordingly, streams with a high SRP supply and relatively low substratum stability and streams with a low SRP supply and high substratum stability may support equivalent levels of bryophyte biomass. Obviously, there will be a threshold of substratum stability, beneath which significant bryophyte biomass cannot be maintained regardless of nutrient regime. Identifying this threshold and determining parameters controlling relationships among substratum instability, nutrient
Fig. 7. Distribution of substratum freezing probability of streams relative to loadings on detrended correspondence analysis (DCA) axes 1 and 2. Y, streams for which evidence of perennial flow is strong; N, evidence for perennial flow is weak. Assignment to categories of substratum freezing probability is based on data provided in Table 2. Arrows indicate direction of increasing concentration of soluble reactive phosphorus ([SRP]) as a function of Axis 1 and increasing disturbance index as a function of Axis 2. All streams are in Arctic Alaska.

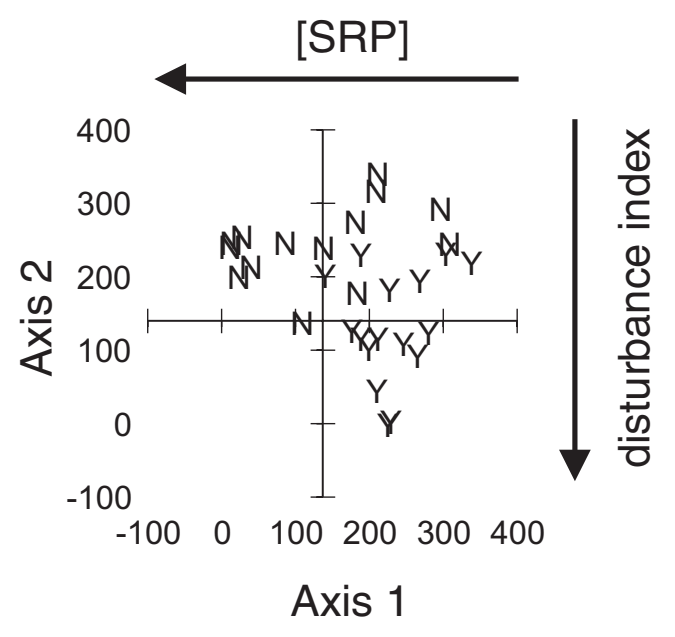

supply, and community resilience should be the focus of further studies of habitat templates and stream communities.

\section{The habitat template and community function}

Filter feeders contributed more than a third of macroinvertebrate biomass in tundra streams, but composed $\leq 2 \%$ of biomass in other stream types. They were virtually absent from glacier streams. In contrast with tundra streams, predators dominated mountain springs. Predator biomass in mountain springs was 100 -fold greater than that in mountain and glacier streams, 41-fold greater than that in tundra streams, and 8-fold greater than that in tundra springs. These results should be interpreted with caution, however, because streams were sampled on single dates within a 29-day period. Consequently, conclusions about community function based on these samples do not account for potential differences in life-history phenology among communities of different stream types, particularly those with perennial flow (i.e., tundra and mountain springs). Nevertheless, the dominance of filter feeders in tundra streams and predators in mountain springs indicates that significant functional contrasts may exist among stream types. For example, the high predator biomass in mountain springs indicates that the scope for top-down control of system productivity is reasonable in these systems, whereas bottom-up factors such as physical disturbance and nutrient supplies are presumed to be most significant in other stream types. In contrast, the retention of organic matter and for upstream-downstream linkage (i.e., Wallace et al. 1977) of stream food webs by filter feeders may be significant only in tundra streams.

\section{The habitat template and the North Slope landscape}

If only headwaters are considered, tundra streams contribute $3 \times 10^{4} \mathrm{~km}$ or $88 \%$ of the total stream length on the east- 
Fig. 8. Relationship between algal taxonomic richness (S) and detrended correspondence analysis (DCA) axes $1(a)$ and 2 (b) for five types of headwater streams. Relationship between chlorophyll $a$ biomass and DCA Axes $1(c)$ and $2(d)$. Relationship between bryophyte biomass and DCA Axes $1(e)$ and $2(f)$. Solid circles, mountain springs; open circles, tundra springs; solid squares, tundra streams; open squares, mountain streams; open triangles, glacier streams. All streams are in Arctic Alaska.
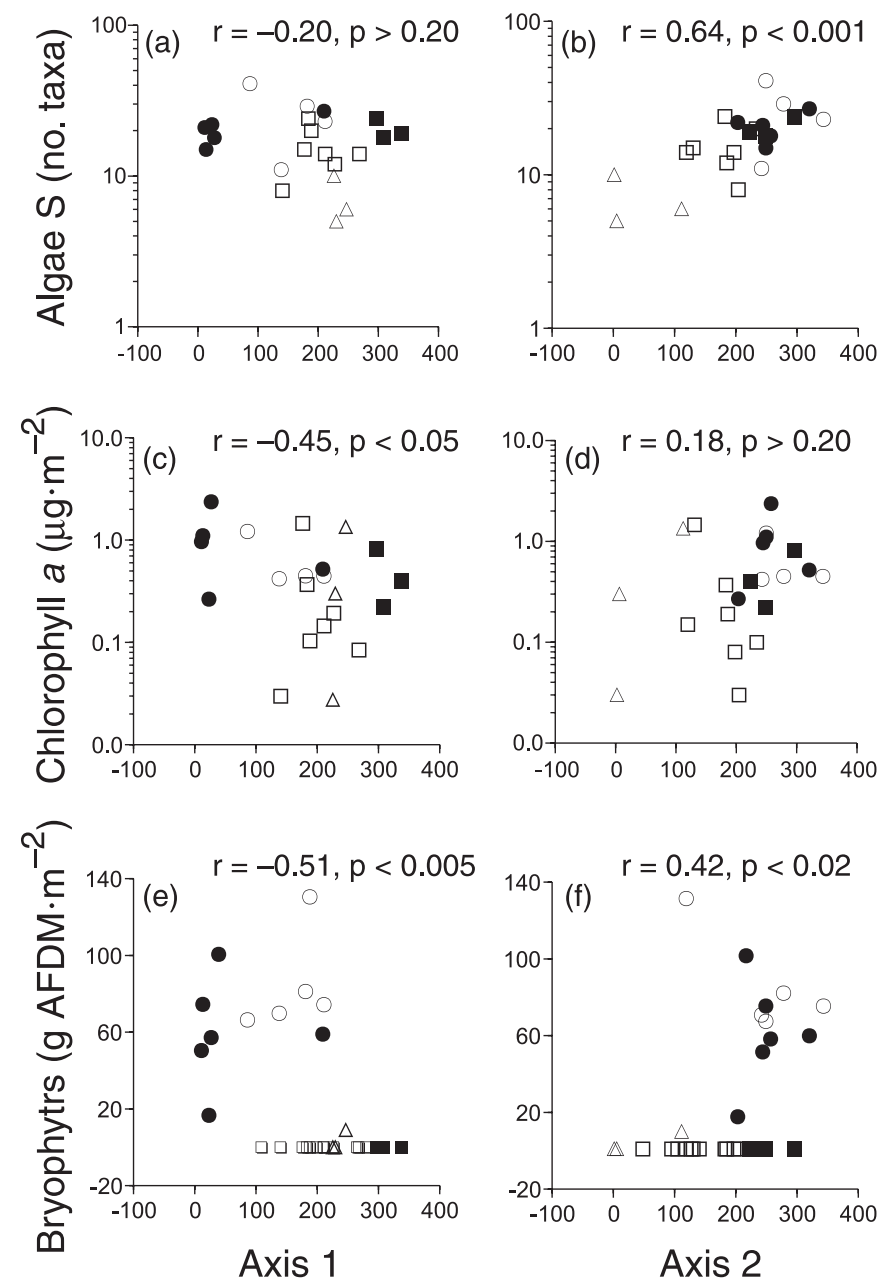

ern North Slope (Craig 1989). Predictions based on our habitat template indicate that the vast majority of the headwater streams of the North Slope have macroinvertebrate communities structured by relatively high substratum stability, a high probability of substratum freezing during winter, and a low nutrient supply.

Compared with tundra streams, mountain and glacier streams contribute $11 \%$ to total stream length, and spring streams contribute only $1 \%$. Although spring streams provide a negligible amount of habitat area, they may have large consequences for biodiversity and food web dynamics of the North Slope landscape. During winter, for example, springs provide $100 \%$ of flowing headwater habitat and critical winter refugia for predators that are unable to tolerate freezing (e.g., perlodid stoneflies, Dolly Varden; Craig 1978, 1989). They may also be important sources for freshwater productivity in this region. Given the average annual temperatures of $5-7{ }^{\circ} \mathrm{C}$ or more, a reasonable annual turnover rate for
Fig. 9. Distribution of total macroinvertebrate biomass among mountain and glacier streams (solid bars), tundra streams (hatched bars), and tundra and mountain springs (open bars). Distribution of total macroinvertebrate biomass reported for 53 streams worldwide (Benke 1993) is shown in gray. Four additional estimates provided by Benke (1993), which exceeded $12 \mathrm{~g} \cdot \mathrm{DM} \mathrm{m} \mathrm{m}^{-2}$ (DM, dry mass), are not shown. These streams had communities dominated by mussels or oligochaetes.

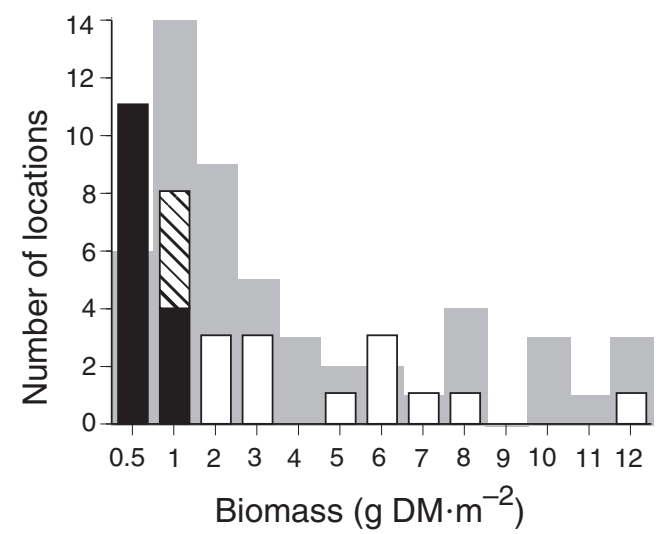

macroinvertebrate assemblages dominated by members of the Diamesinae is 5 (Berg and Helenthal 1991; Nolte and Hoffman 1992). If this rate is accurate, secondary production in mountain springs may approach $20 \mathrm{~g} \mathrm{DM} \cdot \mathrm{m}^{-2} \cdot \mathrm{year}^{-1}$ on average and may exceed $50 \mathrm{~g} \mathrm{DM} \cdot \mathrm{m}^{-2} \cdot \mathrm{year}^{-1}$ in specific springs (A.D. Huryn, unpublished data). Such rates would be considered high for temperate or tropical headwater streams (Benke 1993; Huryn and Wallace 2000). Although these estimates are presumptive, they are also realistic, indicating that extraordinary levels of secondary production may be possible for mountain springs well above the Arctic Circle.

\section{The habitat template and climate change}

The Arctic is warming at an unprecedented rate (IPCC 2001). General circulation models predict that by 2080 , summer temperatures will increase $4.0-7.5^{\circ} \mathrm{C}$ and winter temperatures will increase $2.5-14.0^{\circ} \mathrm{C}$ (IPCC 2001). Coincident with these changes in temperature, precipitation is predicted to increase by $10 \%-20 \%$ in summer and $5 \%-80 \%$ in winter. As warming proceeds, the number of headwater streams with perennial flow or habitats that function as refuges from freezing will likely increase, as will phosphorous supply because of higher rates of weathering combined with an increase in the depth of the active layer of the permafrost (Hobbie et al. 1999; Vincent and Hobbie 2000). Increased precipitation may affect patterns of substrate instability, depending on whether increases occur in the form of more frequent storms during summer or increased snow pack during winter.

The warming trend predicted during this century will likely affect landscape-level patterns of substratum freezing probability and instability and nutrient supply, resulting in shifts in the positions of stream types within the habitat template. For example, as warming proceeds there will likely be a shift from oligotrophic streams with a high probability of substratum freezing (tundra, mountain, glacier streams) to streams with greater supplies of SRP and a greater likeli- 
Fig. 10. Changes in macroinvertebrate community attributes predicted in response to expected pattern of climate change during the next century. D, low (-) and high (+) levels of substratum disturbance; F, low $(-)$, high $(+)$, and uncertain $( \pm)$ probabilities of substratum freezing; P, low (-) and (+) high soluble reactive phosphorus (SRP) supply. Increased precipitation and storm frequency is expected to result in increased intensities of substratum disturbance. Warming is expected to reduce the probability of substratum freezing and increase SRP supply owing to melting of permafrost and exposure of previously frozen sediments to weathering. Changes in the position of macroinvertebrate assemblages within the biplot are predicted to follow the direction of the arrows (e.g., F- D+ P+). Presumably tundra (TND), mountain (MTN) and glacier (GLC) streams will be most affected, while mountain springs (MTNSPR) will be least affected by climate change.

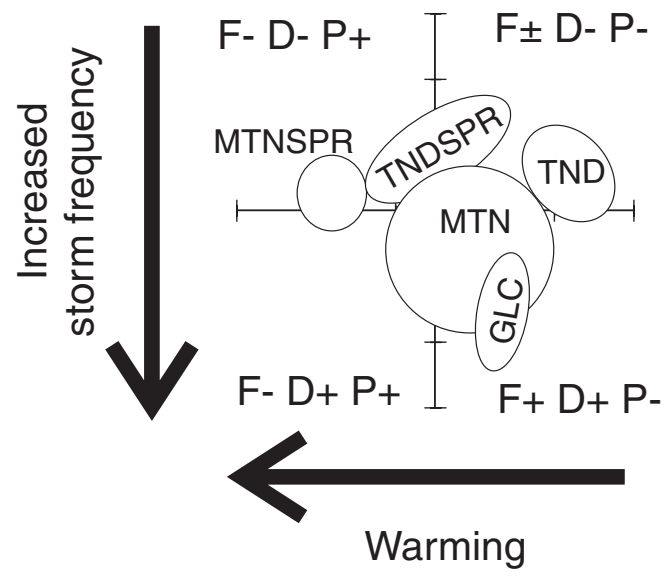

hood of perennial flow during winter (Fig. 10). Increases in precipitation may increase the probability of substratum disturbance, particularly if such increases are in the form of more frequent storms. Compared with other types of streams, mountain springs will presumably be least affected because of their relatively constant discharge from deep and extensive groundwater sources and relatively high nutrient supplies. However, tundra streams, which comprise $88 \%$ of stream length on the North Slope, may be among the most severely affected stream type. Tundra springs will presumably act as sources of colonizers for tundra streams as the major habitat attributes of these two stream types converge (moderate SRP concentrations, perennial flow). Tundra springs may well provide models of what tundra streams may become as the climate warms (Fig. 10). The present forecast of climate change for the near future may thus result in large alterations to the community structure and ecosystem function of the majority of streams in this Arctic landscape.

\section{Acknowledgements}

We thank Mike Warlick and Robert "Butch" Coale (Tundra Copters) for their assistance in the field. Andrew Balser (Arctic Institute of Biology (AIB), University of Fairbanks, Alaska) provided Fig. 1. Michael Chadwick, Vivian Butz Huryn, Moira Ferguson, and three anonymous reviewers provided helpful comments on early drafts of the manuscript. Funding was provided by grants from the National
Science Foundation (NSF DEB-9810222 and NSF OPP9911278).

\section{References}

Benke, A.C. 1993. Concepts and patterns of invertebrate production in running waters. Verh. Internat. Verein. Limnol. 25: 1538.

Benke, A.C., Huryn, A.D., Smock, L.A., and Wallace, J.B. 1999. Length-mass relationships for freshwater macroinvertebrates in North America with particular reference to the southeastern United States. J. North Am. Benthol. Soc. 18: 308-343.

Berg, M.B., and Hellenthal, R.A. 1991. Secondary production of Chironomidae (Diptera) in a north temperate stream. Freshw. Biol. 25: 497-505.

Biggs, B.J.F., Stevenson, R.J., and Lowe, R.L. 1998. A habitat matrix conceptual model for stream periphyton. Arch. Hydrobiol. 143: 21-56.

Bowden, W.B., Finlay, J.C., and Maloney, P.E. 1994. Long-term effects of $\mathrm{PO}_{4}$ fertilization on the distribution of bryophytes in an arctic tundra stream. Freshw. Biol. 32: 445-454.

Brussock, P.P., Brown, A.V., and Dixon, J.C. 1985. Channel form and stream ecosystem models. Water Resour. Bull. 21: 859-866.

Clifford, H.F. 1969. Limnological features of a northern brownwater stream, with special reference to the life histories of aquatic insects. Am. Midl. Nat. 82: 578-597.

Clifford, H.F. 1982. Life cycles of mayflies (Ephemeroptera), with special reference to voltinism. Quaest. Entomol. 18: 15-90.

Craig, P.C. 1978. Movements of stream-resident and anadromous arctic char (Salvelinus alpinus) in a perennial spring on the Canning River, Alaska. Can. J. Fish. Aquat. Sci. 35: 48-52.

Craig, P.C. 1989. An introduction to anadromous fishes in the Alaskan Arctic. Biol. Pap. Univ. Alsk. Inst. of Arct. Biol. 24: 27-54.

Craig, P.C., and McCart, P.J. 1975. Classification of stream types in Beaufort Sea drainages between Prudhoe Bay, Alaska, and the Mackenzie Delta, N.W.T., Canada. Arct. Alp. Res. 7: 183198.

Crosskey, R.W. 1990. The natural history of blackflies. John Wiley \& Sons, Chichester.

Danks, H.V. 1978. Modes of seasonal adaptation in the insects, I. Winter survival. Can. Entomol. 110: 1167-1205.

Duncan, M.J., Suren, A.M., and Brown, S.L.R. 1999. Assessment of streambed stability in steep, bouldery streams: development of a new analytical technique. J. North Am. Benthol. Soc. 18: 445-456.

Frissell, C.A., Liss, W.J., Warren, C.E., and Hurley, M.D. 1986. A hierarchical framework for stream habitat classification: viewing streams in a watershed context. Environ. Manag. 10: 199-214.

Giberson, D.J., and Galloway, T.D. 1985. Life history and production of Ephoron album (Say) (Ephemeroptera: polymitarcidae) in the Valley River, Manitoba. Can. J. Zool. 63: 1668-1674.

Harvey, C.J., Peterson, B.J., Bowden,W.B., Hershey, A.E., Miller, M.C., Deegan, L.A., and Finlay, J.C. 1998. Biological responses to fertilization of Oksrukuyik Creek, a tundra stream. J. North Am. Benthol. Soc. 17: 190-209.

Hershey, A.E., Merritt, R.W., and Miller, M.C. 1995. Insect diversity, life history, and trophic dynamics in Arctic streams, with particular emphasis on black flies (Diptera: Simuliidae). In Arctic and alpine biodiversity. Edited by F.S. Chapin, III, and C. Körner. Springer, Berlin. pp. 283-296.

Hill, M.O., and Gauch, H.G. 1980. Detrended correspondence analysis: an improved ordination technique. Vegetatio, 42: 4758. 
Hobbie, J.E., Peterson, B.J., Bettez, N., Deegan, L., O’Brien, W.J., Kling, G.W., Kipphut, G.W., Bowden, W.B., and Hershey, A.E. 1999. Impact of global climate change on the biogeochemistry and ecology of an Arctic freshwater system. Polar Res. 18: 207214.

Holmes, R.M., Aminot, A., Kerouel, R., Hooker, B.A., and Peterson, B.J. 1999. A simple and precise method for measuring ammonium in marine and freshwater ecosystems. Can. J. Fish. Aquat. Sci. 56: 1801-1808.

Huryn, A.D., and Wallace, J.B. 1987. Local geomorphology as a determinant of macrofaunal production in a mountain stream. Ecology, 68: 1932-1942.

Huryn, A.D., and Wallace, J.B. 2000. Life history and production of stream insects. Annu. Rev. Entomol. 45: 83-110.

IPCC (Intergovernmental Panel on Climate Change). 2001. Climate change 2001: impacts, adaptation, and vulnerability. Contribution of Working Group II to the Third Assessment Report of the Intergovernmental Panel on Climate Change. Edited by J.J. McCarthy, O.F. Canziani, N.A. Leary, D.J. Dokken, and K.S. White. Cambridge University Press, Cambridge, UK.

Irons, J.G., III, and Oswood, M.W. 1992. Seasonal temperature patterns in an arctic and two subarctic Alaskan (USA) streams. Can. J. Zool. 66: 1258-1265.

Irons, J.G., III, Miller, L.K., and Oswood, M.W. 1993. Ecological adaptations of aquatic macroinvertebrates to overwintering in interior Alaska (U.S.A.) subarctic streams. Can. J. Zool. 71: 98108.

Kurtak, D. 1974. Overwintering of Simulium pictipes Hagen (Diptera: Simuliidae) as eggs. J. Med. Entomol. 11: 383-384.

Lake, P.S. 2000. Disturbance, patchiness, and diversity in streams. J. North Am. Benthol. 19: 573-592.

Lowe, R.L., and Pan, Y. 1996. Benthic algal communities as biological monitors. In Benthic algal ecology in freshwater ecosystems. Edited by R.J. Stevenson, M.L. Bothwell, and R.L. Lowe. Academic Press Inc., San Diego. pp. 705-739.

McAuliffe, J.R. 1983. Competition, colonization patterns, and disturbance in stream benthic communities. In Stream ecology: application and testing of general ecological theory. Edited by J.R. Barnes and G.W. Minshall. Plenum Press, New York. pp. 137155.

McCone, B., and Mefford, M.J. 1999. Multivariate analysis of ecological data. Version 4.07. MjM Software, Glenedon Beach, Oregon, USA.

Merritt, R.W., and Cummins, K.W. 1996. An introduction to the aquatic insects of North America. Kendall/Hunt, Dubuque, Iowa.

Miller, M.C., Stout, J.R., and Alexander, V. 1986. Effects of a controlled under-ice oil spill on invertebrates of an arctic and a subarctic stream. Environ. Pollut. Ser. A, 42: 99-132.

Murphy, J., and Riley, J.P. 1962. A modified single solution method for the determination of phosphate in natural waters. Anal. Chim. Acta, 27: 31-36.

Nava, J.A., and Morrison, P. 1974. A note on hot springs in the interior of Alaska. Arctic, 27: 241-243.
Nolte, U., and Hoffman, T. 1992. Fast life in cold water: Diamesa incallida (Chironomidae). Ecography, 15: 25-30.

Olsson, T.I. 1981. Overwintering of benthic macroinvertebrates in ice and frozen sediment in a North Swedish river. Holarct. Ecol. 4: $161-166$.

Oswood, M.W. 1989. Community structure of benthic invertebrates in interior Alaskan (U.S.A.) streams and rivers. Hydrobiologia, 172: $97-110$.

Oswood, M.W., Miller, L.K., and Irons, J.G., III. 1991. Overwintering of freshwater benthic macroinvertebrates. In Insects at low temperature. Edited by R.E. Lee, Jr., and D.L. Denlinger. Chapman and Hall, New York. pp. 361-375.

Oswood, M.W., Irons, J.G., III, and Milner, A.M. 1995. River and stream ecosystems of Alaska. In Ecosystems of the World 22: river and stream ecosystems. Edited by C.E. Cushing, K.W. Cummins, and G.W. Minshall. Elsevier, Amsterdam. pp. 9-32.

Peterson, B., Fry, B., Deegan, L., and Hershey, A. 1993. The trophic significance of epilithic algal production in a fertilized tundra stream. Limnol. Oceanogr. 38: 872-878.

Poff, N.L. 1997. Landscape filters and species traits: towards mechanistic understanding and prediction in stream ecology. J. North Am. Benthol. Soc. 16: 391-409.

Prowse, T.D. 1994. Environmental significance of ice to streamflow in cold regions. Freshw. Biol. 32: 241-259.

Rosgen, D.L. 1994. A classification of natural rivers. Catena, 22: 169-199.

Scarsbrook, M.R., and Townsend, C.R. 1993. Stream community structure in relation to spatial and temporal variation: a habitat templet study of two contrasting New Zealand streams. Freshw. Biol. 29: 395-410.

Slavik, K., Peterson, B.J., Deegan, L.A., Bowden, W.B., Hershey, A.E., and Hobbie, J.E. 2004. Long-term response of the Kuparuk River ecosystem to phosphorous fertilization. Ecology, 85: 939-954.

Southwood, T.R.E. 1988. Tactics, stragtegies and templates. Oikos, 52: 3-18.

Townsend, C.R., Scarsbrook, M.R., and Dolédec, S. 1997a. The intermediate disturbance hypothesis, refugia, and biodiversity in streams. Limnol. Oceanogr. 42: 938-949.

Townsend, C.R., Scarsbrook, M.R., and Dolédec, S. 1997b. Quantifying disturbance in streams: alternative measures of disturbance in relation to macroinvertebrate species traits and species richness. J. North Am. Benthol. Soc. 16: 531-544.

Vincent, W.F., and Hobbie, J.E. 2000. Ecology of arctic lakes and rivers. In Arctic: environment, people, policy. Edited by $\mathrm{M}$. Nuttall and T.V. Callaghan. Harwood Academic Publishers, Reading, UK. pp. 197-232.

Wahrhaftig, C. 1965. Physiographic divisions of Alaska. U.S. Geol. Surv. Prof. Pap. 482.

Wallace, J.B., Webster, J.R., and Woodall, W.R. 1977. The role of filter feeders in flowing waters. Archiv. Hydrobiol. 79: 506-532.

Zar, J.H. 1984. Biostatistical analysis. 2nd ed. Prentice Hall, Englewood Cliffs, N.J. 